\title{
Floristic Composition, Species Richness and Diversity of Campo Rupestre Vegetation from the Itacolomi State Park, Minas Gerais, Brazil
}

\author{
Markus Gastauer ${ }^{1,2}$, Maria Cristina Teixeira Braga Messias ${ }^{3} \&$ João Augusto Alves Meira Neto ${ }^{1,2}$ \\ ${ }^{1}$ Laboratory of Plant Ecology, Department of Plant Biology, Federal University of Viçosa, Viçosa, Minas Gerais, \\ Brazil \\ ${ }^{2}$ Center of Environmental Sciences Floresta-Escola, City of Waters, Frutal, Minas Gerais, Brazil \\ ${ }^{3}$ Department of Biodiversity, Evolution and Environment, Federal University of Ouro Preto, Ouro Preto, Minas \\ Gerais, Brazil
}

Correspondence: João Augusto Alves Meira Neto, Laboratory of Plant Ecology, Federal University of Viçosa, Viçosa, Brazil. Tel: 55-313-899-1955. E-mail: j.meira@ufv.br

Received: May 11, 2012 Accepted: June 11, 2012 Online Published: September 1, 2012

doi:10.5539/enrr.v2n3p115 URL: http://dx.doi.org/10.5539/enrr.v2n3p115

\begin{abstract}
Nevertheless campos rupestres are considered species rich and diverse vegetation formations, phytosociological surveys from the Itacolomi State Park, Minas Gerais, Brazil, are lacking in scientific literature. To close this gap, we compared floristic composition, species richness and diversity from two sites, Lagoa Seca and Calais, both situated within the park. Calais is moderately impacted by extensive pasture, fire, and settling activities. Both surveys contained 15 plots of $10 \times 10 \mathrm{~m}$, cardinality of each species was estimated. Beside species richness, the indexes of Shannon-Wiener, Fisher's $\alpha$, the community richness estimator Jackknife 1 and the numbers of endemic, endangered and invasive species were compared. With 107 species, the moderately impacted Calais showed higher species richness than Lagoa Seca (76 species). The indices of Shannon-Wiener and Fisher's $\alpha$, the community richness estimator, as well as point diversity and spatial turnover derived from the species-area relationship (SAR) indicated higher diversity for Calais. From Lagoa Seca, 30\% of all species are endemic to the Atlantic Rainforest or to Cerrado, and four species are endangered, not any species found in Lagoa Seca is described as an invasive one. On the other hand, 23 species found in Calais are invasive species, only one from all 107 species is endangered. Only 19\% of all species found in Calais are endemic. Nevertheless species richness and diversity differ between both study sites, they are exceptionally high compared to similar vegetation formations from further regions. This justifies the declaration of the park as a local hotspot of biodiversity. Furthermore, our results show that species richness or diversity measures are inappropriate criteria to evaluate the intactness of campo rupestre vegetation. More weight should be put on criteria like numbers of invasive, endemic or endangered species.
\end{abstract}

Keywords: endemism, endangered species, invasive species, conservation, species-area relationship, species richness

\section{Introduction}

In the Brazilian Mountain Ranges, tropical forests and savannahs are displaced by rocky outcrop vegetation types above certain altitudes (usually $900 \mathrm{~m}$, Scolforo \& Carvalho, 2006). These azonal rock fields are species rich ecosystems containing many endemics (Caiafa \&Silva, 2005; Conceição \& Giulietti, 2002; Giulietti, Menezes, Pirani, Meguro, \& Wanderley, 1987; Jacobi, Carmo, \& Vincent, 2008; Messias, Leite, Meira Neto, \& Kozovits, 2011; Pirani, Giuletti, Mello-Silva, \& Meguro, 1994; Romero \& Nakajima, 1999). Although endangered due to the intensification of grazing, fire clearing, continued urbanization, dispersion of invasive plant species, collection of endangered (medical) plants, mining activities and nutrient input from industry and traffic (Pirani, Mello-Silva, \& Giuletti, 2003), still little is known about species composition and diversity of these ecosystems (Almeida, 2008; Messias et al., 2011; Mourão \& Stehmann, 2007).

In Brazil, different types of rocky outcrop vegetation can be distinguished, although this differentiation is not unambiguous (Alves \& Kolbeck, 2010). We adapt the Alves and Kolbeck (2010) system, where campo de 
altitude (Martinelli, Bandeira, \& Bragança, 1989), a term synonym for Brazilian páramos (Safford, 2007), is restricted to granite and nephelin-syenite soils. Canga (sometimes misleadingly called campo rupestre ferruginoso) is bound to ironstone outcrops or lateric crusts (Jacobi, Carmo, Vincent, \& Stehmann, 2007). Finally, campo rupestre are found on quartzite outcrops or white sand only.

The Espinhaço Mountain Range forms the transition zone between the Atlantic Rainforest and the Cerrado biome definition (Instituto Brasileira de Geografia e Estatística [IBGE], 2004). In the Iron Quadrangle, the Southern part of the Espinhaço Mountain Range where the Itacolomi State Park is located, a mosaic of campo rupestre, canga, Seasonal Semideciduous Mountain Forests and associated vegetation forms (Dutra, Garcia, \& Lima, 2009; Peron, 1989), forms an extremely species rich and diverse landscape (Fundação Biodiversitas, 2005).

With at least two species endemic to the park's campos rupestres (Batista, Bianchetti, Nogueira, Pellizzaro, \& Ferreira, 2004; Dutra, Garcia, \& Lima, 2008), the Itacolomi State Park contributes exceedingly to the diversity and species richness of the Iron Quadrangle. Nevertheless, botanical research activities are limited to compile voluminous plant lists (Almeida, 2008), but systematic phytosociological surveys measuring and comparing biological diversity are widely lacking for this region.

The aim of this paper is to present phytosociological surveys from two study sites within and nearby the Itacolomi State Park focusing on two topics: It is first tested whether the species richness and diversity found within and around the park's campos rupestres is above average as described from literature. Whittaker (1972) proposed to partition diversity in point diversity from smallest geographic units and spatial turnover reflecting biotic change or species replacement between these units (Magurran, 2004). Proxies for both partitions are derived from the species-area relationship (SAR) to compare study sites with each other as well as with other surveys from literature. Finally, as both study sites differ in their disturbance regime, different indicators to measure and evaluate the intactness, i.e. the absence of impairments, of campo rupestre vegetation are suggested.

\section{Material and Methods}

\subsection{Study Sites}

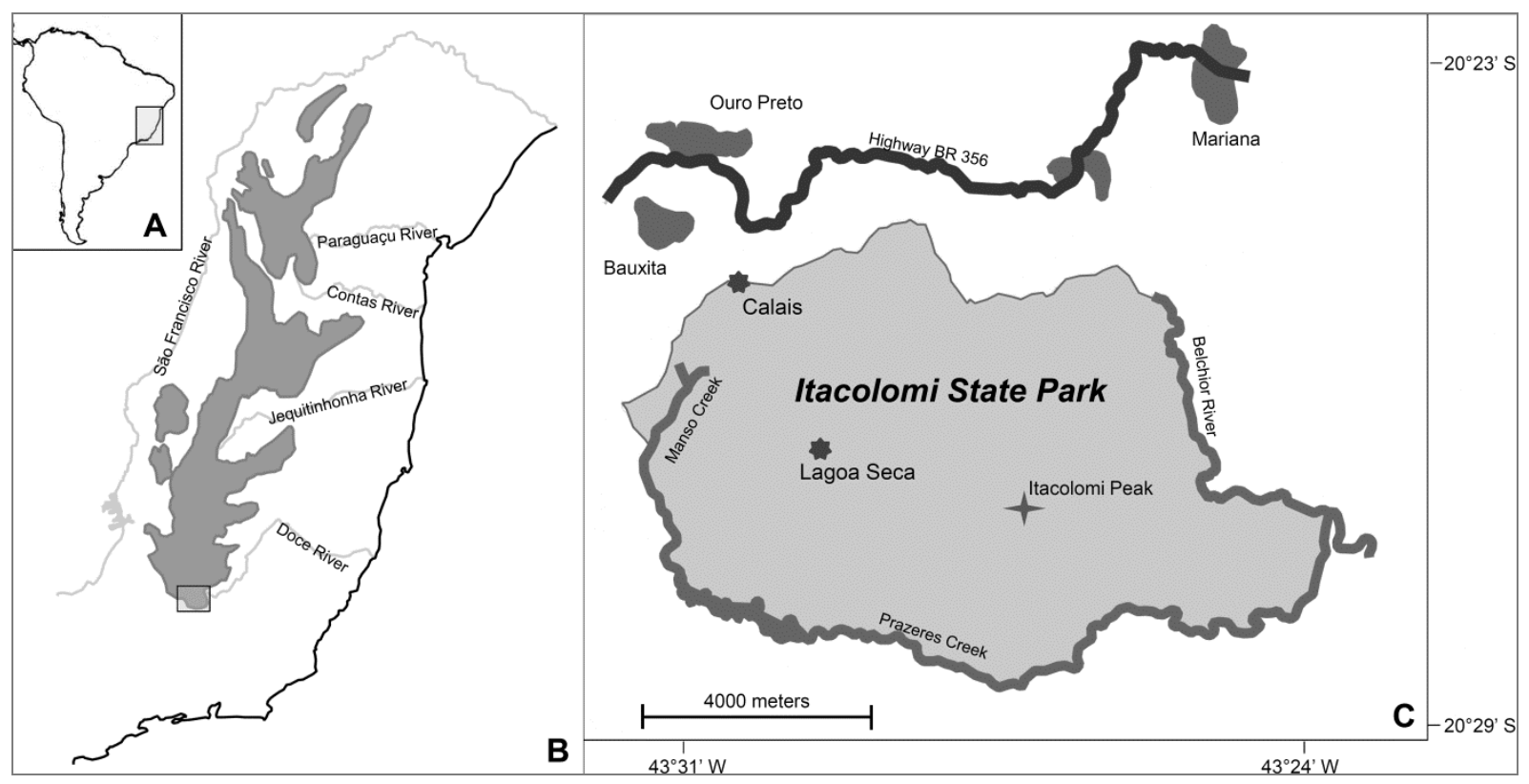

Figure 1.Localization of study sites

Description: Localization of Lagoa Seca and Calais, two study sites from campo rupestre vegetation, in relation to South America (A), the Espinhaço Mountain Range (B, grey areas represent regions above $800 \mathrm{~m}$ a.s.l.) and the Itacolomi State Park (C).

The first study site, Lagoa Seca (dry pond in English), is situated near a periodically inundated area at the coordinates $20^{\circ} 26^{\prime} \mathrm{S}$ and $43^{\circ} 29^{\prime}$ W, $1600 \mathrm{~m}$ a.s.l (Figure 1) within the Itacolomi State Park. The second area, joining the margin of the park and the Ouro Preto urban district of Calais, is located at $20^{\circ} 25^{\prime} \mathrm{S}$ and $43^{\circ} 30^{\prime} \mathrm{W}$ at 
an altitude of $1270 \mathrm{~m}$ a.s.l. Distance between both study sites is about three kilometres.

Both areas show a homogeneous, small-scaled mosaic of gramineous vegetation, small shrubs and quartzite outcrops. While Lagoa Seca is well protected from anthropogenic impacts within the Itacolomi State Park, Calais is moderately disturbed by extensive grazing and burning. Settlement activities such as construction and waste deposits also threaten the area.

The climate of the region corresponds to Köppen's climatic type Cwb (Peel, Finlayson, \& McMahon, 2007) with a rainy summer concentrated from November-March and a dry winter (Nimer, 1989). The average temperature ranges from 17 to $18.5^{\circ} \mathrm{C}$, with an annual precipitation ranging from 1450 to $1800 \mathrm{~mm}$ (Werneck, Pedralli, Koenig, \& Giseke, 2000). According to Harley and Simmons (1986), the climate is moderated by moisture-laden clouds providing humidity as rain or dew throughout most of the year at high altitudes.

\subsection{Data collection}

The phytosociological survey was carried out in February 2009 using the plot method (Mueller-Dombois \& Ellenberg, 1974; Newton, 2007). In each study site, fifteen plots of 10 x $10 \mathrm{~m}$ were arranged in three rows. The distance between plots, both within and between rows, was $10 \mathrm{~m}$.

All species within plots were collected, identified and grouped according to The Angiosperm Phylogeny Group ([APG III], 2009). The cardinality of each species was estimated using a combination of abundance (number of individuals or shoots) and vegetation cover as proposed by Reichelt and Wilmanns (1973, Table 1). All the collected specimens were herborized and deposited in the "Professor José Badini Herbarium" (OUPR) of the Federal University of Ouro Preto.

Table 1. Categories of species cardinality, defined according to Reichelt and Wilmanns (1973) and transformation to vegetation cover, an indirect measure for abundance

\begin{tabular}{|c|c|c|}
\hline Category & Definition & $\begin{array}{c}\text { Transformed } \\
\text { vegetation cover } \\
{[\%]}\end{array}$ \\
\hline $\mathrm{r}$ & $\begin{array}{l}\text { Species with only one individual and less than } 5 \% \\
\text { of vegetation cover }\end{array}$ & 1 \\
\hline+ & $\begin{array}{l}\text { Species with two to five individuals and covering } \\
\text { less than } 5 \%\end{array}$ & 2 \\
\hline 1 & $\begin{array}{l}\text { Species with six to } 50 \text { individuals and less than } 5 \% \\
\text { of vegetation cover }\end{array}$ & 3 \\
\hline $2 \mathrm{~m}$ & $\begin{array}{l}\text { Species with more than } 50 \text { individuals and less than } \\
5 \% \text { of vegetation cover }\end{array}$ & 4 \\
\hline $2 \mathrm{a}$ & Species covering 6 to $15 \%$ & 10 \\
\hline $2 b$ & Species covering 16 to $25 \%$ & 20 \\
\hline 3 & Species covering 26 to $50 \%$ & 38 \\
\hline 4 & Species covering 51 to $75 \%$ & 63 \\
\hline 5 & Species covering 76 to $100 \%$ & 88 \\
\hline
\end{tabular}

\subsection{Floristic Composition}

The presence of invasive, endemic and threatened species was verified. Invasive species are exotic species, i.e. species which do not naturally occur in the studied area, as well as ruderal species indicating disturbances or impacts according to Aranha, Bacchi, and Leitão Filho (1982), Leitão Filho, Aranha, and Bacchi (1982), and Bacchi, Leitão Filho, and Aranha (1984). Endemic species are species endemic to the Cerrado or to the Atlantic rainforest biomes or species occurring in both biomes, but lacking in others. The species endemism data were taken from Stehmann et al. (2009) and Forzza (2012). We consulted Conselho Estadual de Política Ambiental ([COPAM], 2008) for information about threatened species. This is the most recent, but still unofficial red list of Minas Gerais. 


\subsection{Species richness and Diversity Measures}

The number of species or species richness was compared between both study sites.

The biodiversity indices of Shannon-Wiener and Fisher's $\alpha$ were calculated for each study site with the software EstimateS (Colwell \& Coddington, 1994). For that, vegetation cover of each species, derived from its cardinality as shown in Table 1, was used as a measure for abundance.

Based on presence-absence data only, the community richness for each study site was estimated by Jackknife 1 . This estimator was calculated with EstimateS (Colwell \& Coddington, 1994).

The Sørensen similarity has been calculated between all 15 plots from each study site with the software EstimateS (Colwell \& Coddington, 1994). Furthermore, Sørensen and Jaccard similarity has been computed between both study sites, using the same computer package.

\subsection{Species-area Relationships (SAR)}

Species-accumulation curves from both surveys were compared. For that, we calculated the average number of species of groups of two, four, seven, and finally all the 15 plots of each survey. Only neighbouring plots were grouped.

The fitting of each species-accumulation curve by the power model $S=\mathrm{cA}^{\mathrm{z}}$, where $\mathrm{S}$ is the number of species, A is area, c and $\mathrm{z}$ are fitting parameters (Arrhenius, 1921), was defined as species-area relationship (SAR) for surveys. $\log$-transformation linearizes SAR to the form $\log (\mathrm{S})=\mathrm{z} \log (\mathrm{A})+\log (\mathrm{c})$. As $\log (\mathrm{c})$, the intercept of the SAR with the y-axis corresponds to the average extrapolated species richness of one quadrat meter, we interpreted it as a proxy of point diversity. The inclination $\mathrm{z}$ of the linearized curve describes the differences between plots from each survey and might therefore be interpreted as a proxy for spatial turnover (Condit et al., 1996).

\section{Results}

\subsection{Floristic Composition}

In Lagoa Seca, 76 species from 55 genera and 25 families were found. In Calais the species richness was higher, with 107 species from 82 genera and 33 families (Table 2). The number of species per plot varied between 16 and 33 (on average $23.3 \pm 4.98$ ) in Lagoa Seca and from 21 to 43 (on average $31.9 \pm 7.74$ ) in Calais. Twenty two species occurred in both surveys.

Table 2. Species list from two phytosociological surveys of campo rupestre vegetation at Lagoa Seca and Calais, Itacolomi State Park, Minas Gerais, Brazil

\begin{tabular}{ccc} 
Lagoa & Calais Endemism & $\begin{array}{c}\text { Endangerment / } \\
\text { invasive character }\end{array}$ \\
\hline
\end{tabular}

\section{LYCOPODIOPHYTA}

\section{Selaginellaceae}

Selaginella sp.

\section{PTERIDOPHYTA}

\section{Anemiaceae}

Anemia ferruginea Humb. \& Bonpl. ex Kunth

$\mathrm{X}$

Blechnaceae

Blechnum schomburgkii (Klotzsch) C. Chr.

$\mathrm{X}$ CE-ARF**

Dennstaedtiaceae

Pteridium arachnoideum (Kaulf.) Maxon

$\mathrm{X}$

\section{Doryopteridaceae}

Doryopteris ornithopus (Hook. \& Baker) J. Sm

\section{Gleicheniaceae}


Dicranopteris flexuosa (Schrad.) Underw.

X

IP

Polypodiaceae

Pecluma pectinata (L.) M.G. Price

$\mathrm{X}$

ANGIOSPERMS - MAGNOLIIDS

\section{Annonaceae}

Guatteria villosissima A. St.-Hil.

$\mathrm{X} \quad \mathrm{ARF}^{* *}$

Aristolochiaceae

Aristolochia sp.

X

Continued.

Table 2. Continued.

$\begin{array}{ccc}\text { Lagoa } & \text { Seca }\end{array}$ Calais Endemism $\begin{gathered}\text { Endangerment } / \\ \text { invasive character }\end{gathered}$

\section{Bromeliaceae}

Cryptanthus schwackeanus Mez

X

CE-ARF**

\section{Cyperaceae}

Fimbristylis sp.

$\mathrm{X}$

Rhynchospora consanguinea (Kunth) Boeckeler

Rhychnospora corymbosa (L.) Britton

$\mathrm{X}$

Rhychnospora cf. tenuis Link

$\mathrm{X}$

IP

$\mathrm{X}$

IP

Rhynchospora sp.1

$\mathrm{X}$

Rhynchospora sp.2

$\mathrm{X}$

Rhynchospora sp.3

Scleria hirtella Sw.

Scleria sp.

Trilepis microstachya (C.B. Clarke) H. Pfeiff.

Cyperaceae sp.1

Cyperaceae sp.2

Cyperaceae sp.3

Cyperaceae sp.4

\section{Commelinaceae}

Dichorisandra thyrsiflora J.C. Mikan

Tradescantia ambigua Mart.

$\begin{array}{ll} & X \\ X & X \\ & X \\ & X \\ X & X \\ X & \\ X & X \\ & \text { X }\end{array}$

\section{Dioscoreaceae}

Dioscorea sp.

\section{Hypoxidaceae}

Hypoxis decumbens L.

\section{Iridaceae}

Neomarica cf. glauca (Seub. ex Klatt) Sprague

Sisyrinchium vaginatum Spreng.

\section{Orchidaceae}

Coppensia blanchetii (Rchb. f.) Campacci

X

$\mathrm{X}$

X

X

X

CE-ARF**

X

$\mathrm{X}$ 
Coppensia warmingii (Rchb. f.) Campacci $\quad \mathrm{X}$

Epidendrum denticulatum Barb. Rodr.

Habenaria cf. rupicola Barb. Rodr.

Habenaria sp.

Sacoila lanceolata (Aubl.) Garay

Sophronitis sp.

\section{Poaceae}

Andropogon leucostachyus Kunth

Apochloa poliophylla (Renvoize \& Zuloaga) Zuloaga

\& Morrone

Aristida sp.

Axonopus siccus (Nees) Kuhlm.

Chloris sp.

Eragrostis maypurensis (Kunth) Steud.

Ichnanthus bambusiflorus (Trin.) Döll

Melinis minutiflora P. Beauv.

Otachyrium versicolor (Döll) Henrard

Panicum pseudisachne Mez

Panicum wettsteinii Hack.

Paspalum coryphaeum Trin.

Paspalum hyalinum Nees ex Trin.

Paspalum multicaule Poir.

Paspalum notatum Flüggé

Paspalum plicatulum Michx.

Pennisetum setosum (Sw.) Rich.
$\mathrm{X}$

$\mathrm{X}$

$\mathrm{X}$

X

X

$\mathrm{X}$

$\mathrm{X}$ CE-ARF**

$\mathrm{X}$

$\mathrm{X}$

$\mathrm{X}$

$\mathrm{X}$

X X

$\mathrm{X}$

X

X X

X X

$\mathrm{X}$

X

X

X

IP

$\mathrm{X}$

X
IP

EX

IP

IP

VU

CE-ARF**

CE-ARF*

. $x$ IP IP

Continued.

Table 2. Continued.

\begin{tabular}{|c|c|c|c|c|}
\hline & $\begin{array}{c}\text { Lagoa } \\
\text { Seca }\end{array}$ & Calais & Endemism & $\begin{array}{c}\text { Endangerment / } \\
\text { invasive character }\end{array}$ \\
\hline Poa cf. annua L. & & $\mathrm{X}$ & EX & IP \\
\hline Schizachyrium sanguineum (Retz.) Alston & $\mathrm{X}$ & $\mathrm{X}$ & & \\
\hline Sporobolus metallicolus Longhi-Wagner \& Boechat & $\mathrm{X}$ & $\mathrm{X}$ & $\mathrm{CE}^{* *}$ & VU \\
\hline Urochloa decumbens (Stapf) R.D. Webster & & $\mathrm{X}$ & EX & IP \\
\hline Poaceae sp.1 & $\mathrm{X}$ & & & \\
\hline Poaceae sp.2 & $\mathrm{X}$ & $\mathrm{X}$ & & \\
\hline Poaceae sp.3 & & $\mathrm{X}$ & & \\
\hline \multicolumn{5}{|l|}{ Smilaceae } \\
\hline Smilax oblongifolia Pohl ex Grieseb. & $\mathrm{X}$ & & $\mathrm{CE}^{* *}$ & \\
\hline \multicolumn{5}{|l|}{ Velloziaceae } \\
\hline Vellozia compacta Mart. ex Schult. \& Schult. f. & $\mathrm{X}$ & & $\mathrm{CE}^{* *}$ & \\
\hline \multicolumn{5}{|l|}{ Xyridaceae } \\
\hline Xyris cf. plantaginea Mart. & $\mathrm{X}$ & & $\mathrm{CE}^{* *}$ & \\
\hline Xyris sp.1 & $\mathrm{X}$ & & & \\
\hline
\end{tabular}


Xyris sp.2 X

\section{ANGIOSPERMS - EUDICOTS}

Acanthaceae

Ruellia macrantha (Mart. ex Nees) Lindau

X

Amaranthaceae

Amaranthaceae sp.

X

\section{Apiaceae}

Eryngium paniculatum Cav. \& Dombey ex F. X

Delaroche

\section{Apocynaceae}

Oxypetalum appendiculatum Mart.

\section{Araliaceae}

Hydrocotyle quinqueloba Ruiz \& Pav.

\section{Asteraceae}

Acanthospermum australe (Loefl.) Kuntze

Achyrocline satureioides (Lam.) DC

X

IP

Baccharis aphylla (Vell.) DC

X $\quad X$

Baccharis sessiliflora Vahl

Baccharis dracunculifolia DC.

$\mathrm{X}$

Baccharis platypoda DC.

Baccharis reticularia DC.

Baccharis serrulata (Lam.) Pers.

Baccharis sp.

Chaptalia nutans (L.) Pol.

Cyrtocymura scorpioides (Lam.) H. Rob.

Eremanthus crotonoides (DC.) Sch. Bip.

Eremanthus erythropappus (DC.) MacLeish

Eremanthus incanus (Less.) Less.

Eupatorium sp.

Koanophyllon adamantium (Gardner) R.M. King \& H.

Rob.

Mikania nummularia DC.

Mikania sp.

Pterocaulon lanatum Kuntze

Richterago amplexifolia (Gardner) Kuntze

Senecio adamantinus Bong.

Stenocline sp.

Stevia clausseni Sch. Bip. ex Baker

Trichogonia sp.

Vernonia sp.1

Vernonia sp.2

$\mathrm{X}$

\begin{tabular}{|c|c|c|}
\hline K & $\mathrm{X}$ & CE-ARF** \\
\hline \multicolumn{3}{|l|}{ K } \\
\hline & $\mathrm{X}$ & $\mathrm{CE}^{* *}$ \\
\hline K & & $\mathrm{CE}^{* *}$ \\
\hline$x$ & $\mathrm{X}$ & CE-ARF** \\
\hline \multicolumn{3}{|c|}{$\mathrm{X}$} \\
\hline & $\mathrm{X}$ & $\mathrm{CE}^{* *}$ \\
\hline & $\mathrm{X}$ & \\
\hline & $\mathrm{X}$ & \\
\hline & $\mathrm{X}$ & \\
\hline
\end{tabular}

IP

IP

$\mathrm{X} \quad \mathrm{X}$

CE-ARF**

CE-ARF**

$\mathrm{X} \quad \mathrm{X}$

$\mathrm{X}$

$\mathrm{X}$

Continued.

Table 2. Continued. 


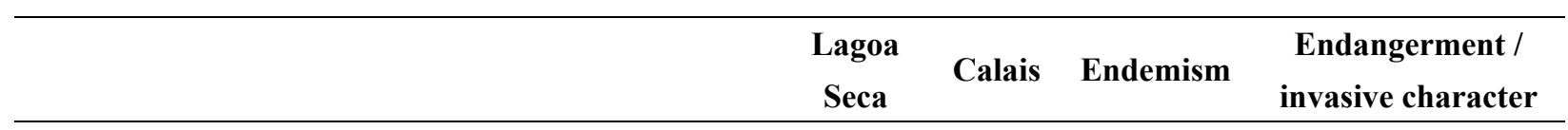

\section{Boraginaceae}

Varronia curassavica Jacq.

X

\section{Campanulaceae}

Lobelia camporum Pohl

X

\section{Droseraceae}

Drosera montana A. St.-Hil.

X

\section{Fabaceae}

Aeschynomene elegans Schltdl. \& Cham.

Chamaecrista flexuosa (L.) Greene

Chamaecrista rotundifolia (Pers.) Greene

Crotalaria sp.

Dalbergia brasiliensis Vogel

Desmodium adscendens (Sw.) DC.

Desmodium barbatum (L.) Benth.

Inga sessilis (Vell.) Mart.

Mimosoideae sp.

Periandra mediterranea (Vell.) Taub.

Senna reniformis(G. Don) H.S. Irwin\& Barneby

Stylosanthes viscosa (L.) Sw.

Zornia reticulata $\mathrm{Sm}$.

X

$\mathrm{X}$

$\mathrm{X}$

$\mathrm{X}$

$\mathrm{X}$

$\mathrm{X}$

$\mathrm{X}$

$\mathrm{X}$

$\mathrm{X}$

$\mathrm{X}$

$\mathrm{X}$

$\mathrm{X}$

$\mathrm{X}$

\section{Lamiaceae}

Hyptis homolophylla Pohl ex Benth.

Hyptis monticola Mart. ex Benth.

\section{Lentibulariaceae}

Genlisea repens Benj.

Utricularia amethystina Salzm. ex A. St.-Hil. \& Girard

\section{Lythraceae}

Cuphea carthagenensis (Jacq.) J. Macbr.

Cuphea sp.

Diplusodon buxifolius (Cham. \& Schltdl.) A. DC.

Malpighiaceae

Banisteriopsis campestris (A. Juss.) Little

Byrsonima variabilis A. Juss.

Heteropterys sp.

\section{Malvaceae}

Sida linifolia Cav.

Wissadula sp.

\section{Melastomataceae}

Cambessedesia hilariana (Kunth) DC.

Lavoisiera sp.

Leandra cf. australis (Cham.) Cogn.
CE-ARF**

X

$\begin{array}{llc}\mathrm{X} & \mathrm{X} & \mathrm{CE} * * \\ \mathrm{X} & & \mathrm{CE}-\mathrm{ARF}^{* * *}\end{array}$

X

$\mathrm{X}$
$\mathrm{X}$

$\mathrm{X}$

$\mathrm{X}$

$\mathrm{CE}^{* *}$

$\begin{array}{ll} & X \\ & X \\ & X\end{array}$

X

X

$\begin{array}{ccc}\mathrm{X} & \mathrm{X} & \mathrm{CE}-\mathrm{ARF}^{* * *} \\ \mathrm{X} & & \\ \mathrm{X} & & \text { ARF* }^{*}\end{array}$


Miconia pepericarpa DC.

Miconia sp.1

Miconia sp.2

Microlicia crenulata Mart.

Microlicia sp.1

Microlicia sp. 2

Microlicia sp. 3

Tibouchina cardinalis (Humb. \& Bonpl.) Cogn.

Tibouchina heteromalla (D. Don) Cogn.

\section{Myrsinaceae}

Ardisia sp.

Myrsine umbellata Mart.

$\begin{array}{ll}\mathrm{X} & \mathrm{CE}^{* *} \\ \mathrm{X} & \\ \mathrm{X} & \end{array}$

$\mathrm{X}$

CE-ARF**

$\mathrm{X}$

$\mathrm{X}$

X

$\begin{array}{lcc} & \text { CE** } \\ & \text { X } & \text { CE-ARF** }\end{array}$

$\mathrm{X}$

$\mathrm{X}$

Table 2. Continued.

\begin{tabular}{|c|c|c|c|c|}
\hline & $\begin{array}{c}\text { Lagoa } \\
\text { Seca }\end{array}$ & Calais & Endemism & $\begin{array}{c}\text { Endangerment / } \\
\text { invasive character }\end{array}$ \\
\hline \multicolumn{5}{|l|}{ Myrtaceae } \\
\hline Myrcia amazonica DC. & & $\mathrm{X}$ & & \\
\hline Myrcia eryocalix DC. & $\mathrm{X}$ & & & \\
\hline Myrcia splendens (Sw.) DC. & $\mathrm{X}$ & $\mathrm{X}$ & & \\
\hline Myrcia subcordata DC. & $\mathrm{X}$ & & $\mathrm{ARF}^{* *}$ & \\
\hline \multicolumn{5}{|l|}{ Polygalaceae } \\
\hline Polygala paniculata L. & $\mathrm{X}$ & $\mathrm{X}$ & & \\
\hline Polygala violacea Aubl. & & $\mathrm{X}$ & & \\
\hline \multicolumn{5}{|l|}{ Proteaceae } \\
\hline Roupala montanaAubl. & $\mathrm{X}$ & & & \\
\hline \multicolumn{5}{|l|}{ Rosaceae } \\
\hline Rubus brasiliensis Mart. & & $\mathrm{X}$ & & IP \\
\hline \multicolumn{5}{|l|}{ Rubiaceae } \\
\hline Diodella teres (Walter) Small & & $\mathrm{X}$ & & IP \\
\hline Borreriaverticillata (L.) G. Mey & & $\mathrm{X}$ & & IP \\
\hline \multicolumn{5}{|l|}{ Rutaceae } \\
\hline Dictyoloma vandellianum A. Juss. & & $\mathrm{X}$ & & \\
\hline \multicolumn{5}{|l|}{ Salicaceae } \\
\hline Casearia sylvestris Sw. & & $\mathrm{X}$ & & \\
\hline \multicolumn{5}{|l|}{ Sapindaceae } \\
\hline Matayba marginata Radlk. & & $X$ & $\mathrm{CE}-\mathrm{ARF} * *$ & \\
\hline \multicolumn{5}{|l|}{ Solanaceae } \\
\hline Brunfelsia brasiliensis (Spreng.) L.B. Sm. \& Downs & $\mathrm{X}$ & & $\mathrm{CE}-\mathrm{ARF}^{* *}$ & \\
\hline Schwenckia americana Rooyen ex L. & & $\mathrm{X}$ & & \\
\hline Solanum americanum Mill. & & $\mathrm{X}$ & & IP \\
\hline Solanum cf. granulosoleprosum Dunal & $\mathrm{X}$ & $\mathrm{X}$ & - & \\
\hline
\end{tabular}




\section{Verbenaceae}

Lantana camara L.

X IP

Lantana fucata Lindl. $\mathrm{X} \quad \mathrm{IP}$

Lippia hermannioides Cham. $\mathrm{X} \quad \mathrm{CE} * *$

Stachytarpheta commutata Schauer

$\mathrm{CE}^{* *} \quad \mathrm{CR}$

161 species

76

107

Description: Species list from two phytosociological surveys of campo rupestre vegetation at Lagoa Seca and Calais, Itacolomi State Park, Minas Gerais, Brazilwith endemism to the Cerrado or Atlantic Rainforest biomes, and further information about endangerment and their invasive character. ARF is species endemic to the Atlantic Rainforest biome; $\mathrm{CE}$ is endemic to the Cerrado biome, CE-ARF is endemic to Cerrado and Atlantic Rainforest biomes, EX is exotic species, CR is critically endangered, IP is invasive species, VU is vulnerable threatened according to COPAM (2008). * Information from Stehmann et al. (2009), ** information from Forzza (2012).

The most abundant families in both surveys were Asteraceae, Poaceae, Cyperaceae and Melastomataceae. The family Fabaceae, well-represented in Calais, was absent in Lagoa Seca. Orchidaceae showed a greater richness in the Lagoa Seca area (6 species) compared with Calais (1 species).

From the total of 161 collected species in both study sites, four are considered as endangered according to COPAM (2008): Richterago amplexifolia, Coppensia warmingii and Stachytarpheta commutata, which occurred only in the Lagoa Seca area, while the fourth, Sporobolus metallicolus, was found in both study sites.

Twenty two species occurring in Calais, but none of those from the Lagoa Seca area, were considered invasive species (Table 2). Three of them, Melinis minutiflora, Poa annua, and Urochloa decumbens, are species introduced to South America by humans.

From all 161 collected species, 36 were restricted to the Atlantic Rainforest or the Brazilian Cerrado biomes. Twenty three of all endemic species were found in the Lagoa Seca area (30\% of all species from this survey), while the Calais survey contained only 20 species endemic to the Atlantic Rainforest or the Cerrado biome (19\% of species found within this survey, Figure 2).
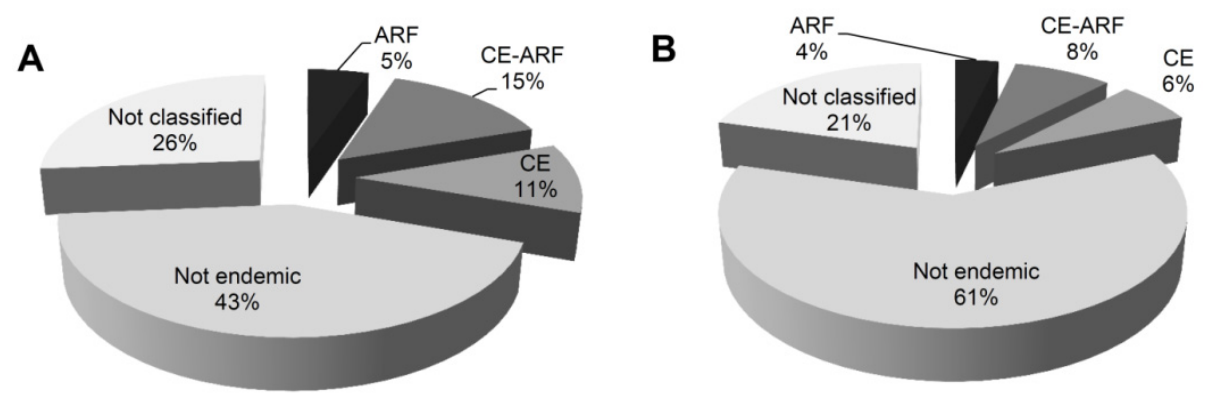

Figure 2. Percentage of species endemic to the Atlantic Rainforest or the Cerrado biome

Description: Percentage of species endemic to the Atlantic Rainforest or the Cerrado biome found in Lagoa Seca (A) and Calais (B), two phytosociological surveys of campo rupestre vegetation, Itacolomi State Park, Minas Gerais, Brazil. ARF is the percentage of species occurring only in the Atlantic Rainforest biome, CE is the percentage of species occurring only in the Cerrado biome, and CE-ARF is the percentage of species endemic to both biomes.

\subsection{Biodiversity Measures}

Due to the dominance of Melinis minutiflora in Calais, the indices of Shannon-Wiener as well as Fisher's $\alpha$ show higher biodiversity for the Calais area. The estimator Jackknife 1 indicated lower community richness for the Lagoa Seca area (Figure 3). 
Table 3. Biodiversity indices of Lagoa Seca and Calais, two areas of campo rupestre vegetation

\begin{tabular}{lcc}
\hline & Lagoa Seca & Calais \\
\hline$H^{\prime}$ & 3.49 & 3.58 \\
$\alpha$ & $17.20 \pm 0.99$ & $24.23 \pm 1.18$
\end{tabular}

Description: Biodiversity indices of Lagoa Seca and Calais, two areas of campo rupestre vegetation, Itacolomi State Park, Minas Gerais, Brazil, derived from phytosociological surveys. H' is Shannon-Wiener index and $\alpha$ is mean Fisher's $\alpha \pm$ standard deviation

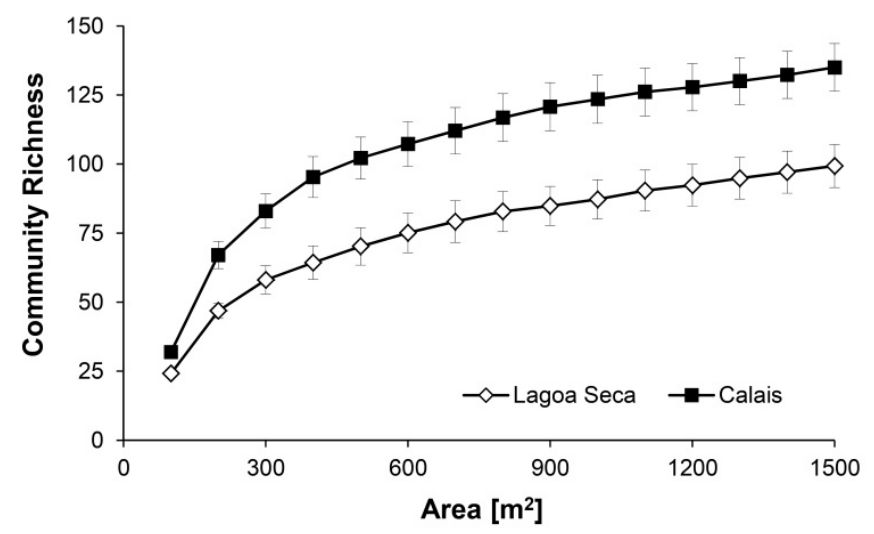

Figure 3.Community richness estimators Jackknife 1 for Lagoa Seca and Calais

Description: Community richness estimators Jackknife 1 for Lagoa Seca and Calais, two phytosociological surveys from campo rupestre vegetation, Itacolomi State Park, Minas Gerais, Brazil.

Measured using Sørensen similarity, the floristic composition of plots is more homogeneous within the Lagoa Seca survey $(0.550 \pm 0.129)$ than in Calais $(0.453 \pm 0.123)$.

The Sørensen similarity between both surveys is 0.240 , the Jaccard similarity 0.158 .

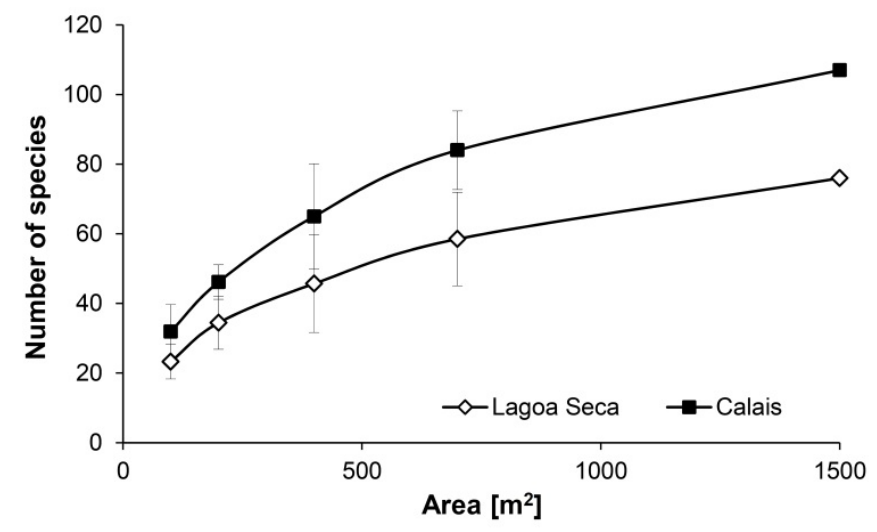

Figure 4. Species-accumulation curves from Lagoa Seca and Calais

Description: Species-accumulation curves from Lagoa Seca and Calais, two phytosociological surveys from campo rupestre vegetation, Itacolomi State Park, Minas Gerais, Brazil. Vertical bars indicate standard deviation. The last point of each series represents survey's species richness and is therefore a unique integer value lacking standard deviation. 
The species-accumulation curves of both study sites did not stabilize within the area analysed in both surveys (Figure 4). Their fittings with the power model show strong correlation coefficients (Lagoa Seca: Number of species $=3.308$ area $^{0.434}, \mathrm{r}^{2}=0.9915$; Calais: Number of species $=4.156$ area $\left.^{0.4519}, \mathrm{r}^{2}=0.9908\right)$. Linearized after logarithmic transformation, both regressions showed high significance (Lagoa Seca: $F_{1 ; 3}=350.9, p<0.001$; Calais: $\left.F_{1 ; 3}=302.8, p<0.001\right)$. This linear regression indicated slightly higher point diversity and spatial turnover for the Calais area (intercept or point diversity: $0.6187 \pm 0.0679$, slope or spatial turnover 0.4519 $\pm 0.0259)$ than for Lagoa Seca (intercept: $0.5197 \pm 0.0607$, slope: $0.4343 \pm 0.0232$ ).

\section{Discussion}

Both study sites showed high levels of species richness compared to other phytosociological studies of campo rupestre and similar vegetation forms (Conceição \& Giuletti, 2002; Jacobi et al., 2008; Lemes, 2009). The Shannon-Wiener index showed higher diversity for both study sites in and around Itacolomi State Park than for quartzite-sandstone campos rupestres in the Pai Inácio Mountains, in Chapada Diamantina, Bahia, Brazil (Conceição, Giuletti, \& Meirelles, 2007). These comparisons give further evidences to the high species richness and diversity already related for the park (Almeida, 2008) and the Iron Quadrangle (Fundação Biodiversitas, 2005) justifying the park's classification as a local hotspot of biodiversity.

The inclination of the linearized SAR is around 0.25 for terrestrial plants (Rosenzweig, 1995). Within our surveys this value is nearly doubled, with 0.43 (Lagoa Seca) and 0.45 (Calais). This might be a consequence of a small sampling area (Dolnik \& Breuer, 2008) and non-contiguous plot design (Dengler, 2008). Nevertheless, the SAR's high slope values indicated high spatial turnover or beta diversity for the Itacolomi State Park, which have already been described for rock fields in general (Jacobi et al., 2007).

Low similarities between both study sites reinforce the affirmation of campos rupestres being species rich ecosystems with a high degree of endemism (Giulietti et al., 1987; Menini Neto, Alves, Barros, \& Forzza, 2007; Nakajima \& Semir, 2001) and highlight once more the importance of the Itacolomi State Park.

Similar Shannon-Wiener diversity index values were found for Cerrado vegetation (Neri, Meira Neto, Silva, Martins, \& Batistia, 2007), while Atlantic Rainforest sites - either evergreen or deciduous - of nearby regions are more diverse (Silva,Martins, Meira Neto, \& Souza, 2004; Werneck et al., 2000).

Fisher's $\alpha$ ranges from 25 to 195.1 for tropical forests (Losos \& Leigh Jr., 2004) and from 12.60 ( \pm 0.73 , Andrade et al., 2002) to 19.83 ( \pm 1.84 , Marimon \& Haridasan, 2005) for Cerrado vegetation. Congruently with the index of Shannon-Wiener, Fisher's $\alpha$ indicates diversity for campo rupestre vegetation between that from Cerrado vegetation and that from tropical forests. Its ranking between savannah and forest vegetation highlights the localization of the campos rupestres from the Espinhaço Mountain Range in the ecotone between the Cerrado and the Atlantic Rainforest biome.

Nevertheless both study sites show high levels of species richness and diversity, those of Calais are even higher than that of Lagoa Seca. This is an unexpected result, because Lagoa Seca is the better protected area, while evidences for anthropogenic impacts were found during survey.

Although these impacts were not quantified, more registered species, higher community richness, higher biodiversity indices of Shannon-Wiener and Fisher's $\alpha$, lower similarity between plots as well as higher point diversity and spatial turnover in Calais support the intermediate disturbance hypothesis (Connell, 1978). According to this well accepted hypothesis (e.g. Molino \& Sabatier, 2001), species richness and diversity are at maximum when disturbances are neither too rare nor too frequent because in this case ruderal, invasive or pioneer species are able to coexist with competitive ones. The presence of 22 invasive species contributed to the higher species richness in Calais and supports the hypothesis because anthropogenic disturbances prevent competitive exclusion of these species (Hughes, 2010; Sax \& Gaines, 2003).

However, as outlined by Hughes (2010), the relationship between disturbance and diversity operates in both directions, since disturbances influence diversity, changing the response to future disturbances (Hughes, Byrnes, Kimbro, \& Stachowicz, 2007; Lyons, Brigham, Traut, \& Schwartz, 2005). This and the lack of true replicates within our research impede generalizations. Further surveys are necessary to test the pattern before its final acceptance.

Although there are no true replicates, this study shows that species richness and diversity are poor predictors of the intactness of campo rupestre vegetation. Therefore, further parameters should be consulted for their evaluation (Usher, 1980).

High number of exotic and invasive species decrease the intactness of the species richer Calais. On the other hand, Lagoa Seca holds more endangered species than Calais. Furthermore, there are fewer orchid species in the 
better-accessible Calais. Some of them, especially Coppensia spp. and Epidendrum denticulatum, are popular ornamental plants with market values. Collecting activities in the less protected Calais area might explain the lack of most orchids in this study site.

Recent studies (e.g. Liebsch, Marques, \& Goldenberg, 2008, Gastauer \& Meira Neto, unpublished data) highlight the presence of endemic species as indicators for habitat intactness. As campo rupestre vegetation from the Espinhaço Mountain Range is situated on the ecotone between the Cerrado and Atlantic Rainforest biome, endemics from both biomes are expected emphasising the transitional character of this vegetation between both biomes (Benites, Caiafa, Mendonça, Schaefer, \& Ker, 2003).

The absolute number of species endemic to the Atlantic Rainforest and the Cerrado biome does not differ between both study sites. But due to higher species richness, the percentage of endemic species is hence less in the impacted Calais than in Lagoa Seca.

We are aware that reduced percentages of endemic species might be due to a dilution effect because of the presence of invasive species increasing overall species richness as observed in Calais. But we can also imagine that endemic species as well as endangered ones show higher risk to go extinct under regimes of high disturbances. Therefore, we suggest the criterion "percentage of endemic species" as an indicator to evaluate the intactness of campo rupestre vegetation in further research activities. The presence of around one third of all species endemic to the biomes Atlantic Rainforest and Cerrado should be used as a reference for further surveys in campos rupestres.

\section{Conclusions}

Our study highlights the exceptional species richness and diversity found in the campo rupestre vegetation from the Itacolomi State Park. Intermediate diversity as well as the presence of species endemic to the Atlantic Rainforest and the Cerrado biome underline the transitional character of campo rupestre vegetation from the Espinhaço Mountain Range between both biomes.

We showed that species richness and diversity are poor indicators for the intactness of campo rupestre vegetation and suggest further parameters such as number of endangered, exotic or invasive species, pauperization of ornamental or medical plants as well as percentage of endemic species as more robust indicators. We suggest a magnitude of $30 \%$ of species endemic to the Atlantic Rainforest and the Cerrado biome for intact campos rupestres patches.

\section{References}

Almeida, G. S. S. (2008). Asteraceae Dumort. nos campos rupestres do Parque Estadual do Itacolomi, Minas Gerais, Brasil. Ph.D thesis, Universidade Federal de Vicosa, Viçosa.

Alves, R. J. V., \& Kolbeck, J. (2010). Can campo rupestre vegetation be floristically delimited based on vascular plant genera? Plant Ecology, 207, 67-79. http://dx.doi.org/10.1007/s11258-009-9654-8

Andrade, L. A. Z., Felfili, J. M., \& Violatti, L. (2002). Fitossociologia de uma área de cerrado denso na RECOR-IBGE, Brasília-DF. Acta Botanica Brasilica, 16,225-240.

Angiosperm Phylogeny Group III. (2009). An update of the Angiosperm Phylogeny Group classification for the orders and families of flowering plants: APG III. Botanical Journal of the Linnean Society161, 105-121. http://dx.doi.org/10.1111/j.1095-8339.2009.00996.x

Aranha, C., Bacchi, O., \& Leitão Filho, H. F. (1982). Plantas invasoras de Culturas, volume 2. São Paulo: HUCITEC.

Arrhenius, O. (1921). Species and area. Journal of Ecology 9, 95-99.

Bacchi, O., Leitão Filho, H. F., \& Aranha, C. (1984). Plantas invasoras de culturas, volume 3. São Paulo, BR: HUCITEC.

Batista, J. A. N., Bianchetti, L. B., Nogueira, R. E., Pellizzaro, K. F., \& Ferreira, F. E. (2004). The genus Habenaria (Orchidaceae) in the Itacolomi State Park, Minas Gerais, Brazil. Sitientibus série Ciências Biologicas, 4(1/2), 25-36.

Benites, V. M., Caiafa, A. N., Mendonça, E. S., Schaefer, C. E., \& Ker, J. C. (2003). Solos e vegetação nos complexos rupestres de altitude da Mantiqueira e do Espinhaço. Floresta e Ambiente, 10,76-85.

Caiafa, N. A., \& Silva, A. F. (2005). Composição floristica e espectro biológico de um campo de altitude no Parque Estadual da Serra do Brigadeiro, Minas Gerais - Brasil. Rodriguésia, 56, 163-173. 
Colwell, R. K., \& Coddington, J. A. (1994). Estimating terrestrial biodiversity through extrapolation. Philosophical Transactions of the Royal Society B, 345, 101-118.

Conceição, A. A., \& Giulietti, A. M. (2002). Composição florística e aspectos estruturais de campo rupestre em dois platôs do Morro do Pai Inácio, Chapada Diamantina, Bahia, Brasil. Hoehnea 29, 37-48.

Conceição, A. A., Giulietti, A. M., \& Meirelles, S. T. (2007). Ilhas de vegetação em afloramentos de quartzito-arenito no Morro do Pai Inácio, Chapada Diamantina, Bahia, Brasil. Acta Botanica Brasilica, 21, 335-347.

Condit, R., Hubbell, S. P., Lafrankie, J. V., Sukumar, R., Manokaran, N., Foster, R. B., \& Ashton, P. S. (1996). Species-area and species-individual relationships for tropical trees: a comparison of three 50-ha plots. Journal of Ecology, 84, 549-562.

Connell, J. H. (1978). Diversity in tropical rain forests and coral reefs.Science, 199, 1302-1310. Retrieved March 4, 2011, from http://www.sciencemag.org

Conselho Estadual de Política Ambiental. (2008). Lista das espécies ameaçadas de extinção da flora no Estado de Minas Gerais. Deliberação Conselho Estadual de Política Ambiental N ${ }^{0} 367$, Anexo I. Retrieved Fevereiro 16, 2009, from http://www.siam.mg.gov.br/sla/download.pdf?idNorma=9450

Dengler, J. (2008). Pitfalls in small-scale species-area sampling and analysis. Folia Geobotanica, 43, 269-287. http://dx.doi.org/10.1007/s12224-008-9014-9

Dolnik, C., \& Breuer, M. (2008). Scale dependency in the species-area relationship of plant communities. Folia Geobotanica, 43, 305-318.http://dx.doi.org/10.1007/s12224-008-9019-4

Dutra, V. F., Garcia, F. C. P., \& Lima, H. C. (2008). Caesalpinioideae (Leguminosae) nos campos rupestres do Parque Estadual do Itacolomi, MG, Brasil. Acta Botanica Brasilica, 22, 547-558.

Dutra, V. F., Garcia, F. C. P., \& Lima, H. C. (2009). Papilionoideae (Leguminosae) nos campos rupestres do Parque Estadual do Itacolomi, MG, Brasil. Acta Botanica Brasilica,23, 145-159.

Forzza, R. C. (coord.). (2012). Lista de Espécies da Flora do Brasil. Retrieved March 2, 2012, from http://floradobrasil.jbrj.gov.br/2010

Fundação Biodiversitas (Eds.). (2005). Biodiversidade em Minas Gerais: um atlas para sua conservacão. Belo Horizonte, BR: Fundação Biodiversitas.

Giulietti, A. M., Menezes, N. L., Pirani J. R., Meguro, M., \& Wanderley, M. G. L. (1987). Flora da Serra do Cipó, Minas Gerais: Caracterização e lista das espécies. Boletim de Botânica da Universidade de São Paulo, 9, $1-151$.

Harley, R. M., \& Simmons, N. A. (1986). Florula of Mucugê, a descriptive check-list of a campo rupestre area. Ardingly, West Sussex, UK: Kew, Royal Botanic Gardens, Kew.

Hughes, A. R., Byrnes, J.E., Kimbro, D.L., \& Stachowicz, J. J. (2007). Reciprocal relationships and potential feedbacks between biodiversity and disturbance. Ecology Letters, 10, 849-864. http://dx.doi.org/10.1111/j.1461-0248.2007.01075.x

Hughes, A. R. (2010). Disturbance and Diversity: An ecological chicken and egg problem. Nature Education Knowledge, 1, 26.

Instituto Brasileiro de Geografia e Estatística. (2004). Mapa de Vegetação do Brasil. $3^{\text {rd }}$ edition. Brasilia, BR: Instituto Brasileiro de Geografia e Estatística.

Jacobi, C. M., Carmo, F. F., Vincent, R. C., \& Stehmann, J. R. (2007). Plant communities on ironstone outcrops: a diverse and endangered Brazilian ecosystem. Biodiversity \& Conservation, 16, 2185-2200. http://dx.doi.org/10.1007/s10531-007-9156-8

Jacobi, C. M., Carmo, F. F., \& Vincent, R. C. (2008). Estudo fitossociológico de uma comunidade vegetal sobre canga como subsídio para a reabilitação de áreas mineradas no Quadrilátero Ferrífero, MG. Revista Árvore, $32,345-353$.

Leitão Filho, H. F., Aranha, C., \& Bacchi, O. (1982). Plantas invasoras de culturas, volume 1. São Paulo, BR: HUCITEC.

Lemes, F. O. A. (2009). Relações florísticas, fitossociológicas e aspectos edáficos de comunidades de campos rupestres da Serra do Itacolomi e Serra do Ouro Branco, Minas Gerais. M.Sc. thesis, Universidade Federal de Ouro Preto, Ouro Preto. 
Liebsch, D., Marques, M. C. M., \& Goldenberg, R. (2008). How long does the Atlantic Rain Forest take to recover after a disturbance? Changes in species composition and ecological features during secondary succession. Biological Conservation, 141, 1717-1725.http://dx.doi.org/10.1016/j.biocon.2008.04.013

Losos, E. C., \& Leigh Jr, E. G. (Eds.). (2004). Tropical forest diversity and dynamism.Findings from a large-scale plot network. Chicago, IL: The University of Chicago Press.

Lyons, K. G., Brigham, C. A., Traut, B. H., \& Schwartz, M. W. (2005). Rare species and ecosystem functioning. Conservation Biology, 19, 1019-1024. http://dx.doi.org/10.1111/j.1523-1739.2005.00106.x

Magurran, A. E. (2004). Measuring Biological Diversity. Oxford, UK: Blackwell Publishing.

Marimon Jr, B. H., \& Haridasan, M. (2005). Comparação da vegetação arbórea e características edáficas de um cerradão e um cerrado sensu stricto em áreas adjacentes sobre solo distrófico no leste de Mato Grosso, Brasil. Acta Botanica Brasilica, 19, 913-926.

Martinelli, G., Bandeira, J., \& Bragança, J. O. (1989). Campos de Altitude. Rio de Janeiro: Ed. Index.

Menini Neto, L., Alves R. J. V., Barros F., \& Forzza R. C. (2007). Orchidaceae do Parque Estadual de Ibitipoca, MG, Brasil. Acta Botanica Brasilica, 21, 687-696.

Messias, M. C. T. B., Leite, M. G. P., Meira Neto, J. A. A., \& Kozovits, A. R. (2011). Life-form spectra of quartzite and itabirite rocky outcrop sites, Minas Gerais, Brazil. Biota Neotropica, 11(1), 1-20. http://dx.doi.org/10.1590/S1676-06032011000200026

Molino, J. F., \& Sabatier, D. (2011). Tree diversity in tropical rain forests: A validation of the intermediate disturbance hypothesis. Science, 294, 1702-1704. http://dx.doi.org/10.1126/science.1060284

Mourão, A., \& Stehmann, J. R. (2007). Levantamento da flora do campo rupestre sobre canga hematítica couraçada remanescente na Mina do Brucutu, Barão de Cocais, Minas Gerais, Brasil. Rodriguésia, 58, 775-786.

Mueller-Dombois, D., \& Ellenberg, H. (1974). Aims and methods of vegetation ecology.New York, NY: John Wiley \& Sons.

Nakajima, J. N., \& Semir, J. (2001). Asteraceae do Parque Nacional da Serra da Canastra, Minas Gerais, Brasil. Revista Brasileira de Botânica, 24, 471-478.

Neri, A. V, Meira Neto, J. A. A., Silva, A. F., Martins, S. V., \& Batista, M. L. (2007). Análise da estrutura de uma comunidade lenhosa em área de cerrado sensu stricto no município de Senador Modestino Gonçalves, norte de Minas Gerais, Brasil. Revista Árvore, 31, 123-134.

Newton, A. C. (2007). Forest ecology and conservation: a handbook of techniques. Oxford, UK: Oxford University Press.

Nimer, E. (1989). Climatologia do Brasil. Rio de Janeiro: Instituto Brasileira de Geografia e Estatística.

Peel, M. C., Finlayson, B. L., \& McMahon, T. A. (2007). Updated world map of the Köppen-Geiger climate classification. Hydrology and Earth System Science, 11, 1633-1644. http://dx.doi.org/10.5194/hess-11-1633-2007

Peron, M. V. (1989). Listagem preliminar da flora fanerogâmica dos campos rupestres do Parque Estadual do Itacolomi - Ouro Preto/Mariana, MG. Rodriguésia, 67, 63-69.

Pirani, J. R., Giuletti, A. M., Mello-Silva, R., \& Meguro, M. (1994). Checklist and patterns of geographic distribution of the vegetation of Serra do Ambrósio, Minas Gerais, Brazil. Revista Brasileira de Botânica, 67, 133-147.

Pirani, J. R., Mello-Silva, R., \& Giuletti, A. M. (2003). Flora de Grão-Mogol, Minas Gerais, Brasil. Boletim de Botânica da Universidade de São Paulo, 21, 1-24.

Reichelt, G., \& Wilmanns, O. (1973). Vegetationsgeographie. Braunschweig, GE: Westermann.

Romero, R., \& Nakajima, J. N. (1999). Espécies endêmicas do Parque Nacional da Serra da Canastra, Minas Gerias. Revista Brasileira de Botânica, 22, 259-265.

Rosenzweig, M. L. (1995). Species diversity in Space and Time. Cambridge, UK: Cambridge University Press.

Safford, H. D. (2007). Brazilian Páramos IV. Phytogeography of the campos de altitude. Journal of Biogeography, 34, 1701-1722. http://dx.doi.org/10.1111/j.1365-2699.2007.01732.x

Sax, D. F., \& Gaines, S. D. (2003). Species diversity: from global decreases to local increases. Trends in Ecology 
and Evolution, 18, 561-566. http://www.dx.doi.org/10.1016/s0169-5347(03)00224-6

Scolforo, J. R.; \& Carvalho, L. M. T. (2006). Mapeamento e inventário da flora nativa e dos reflorestamentos de Minas Gerais. Lavras, BR: Editora UFLA.

Silva, N. R. S., Martins, S. V., Meira Neto, J. A. A., \& Souza, A. L. (2004). Composição florística e estrutura de uma Floresta Estacional Semidecidual Montana em Viçosa, MG. Revista Árvore, 28, 397-405.

Stehmann, J. R., Forzza, R. C., Salino, A., Sobral, M., Costa, D. P., \&Kamino, L. H. Y. (Eds.).(2009). Plantas da Floresta Atlântica. Rio de Janeiro, BR: Instituto de Pesquisas Jardim Botânico do Rio de Janeiro.

Usher, M. B. (1980). An assessment of conservation values within a large site of special scientific interest in North Yorkshire. Field Studies, 5, 323-348.

Werneck, M. S., Pedralli, G., Koenig, R., \& Giseke, L. F. (2000). Florística e estrutura de três trechos de uma floresta semidecídua na Estação Ecológica do Tripuí, Ouro Preto, MG. Revista Brasileira de Botânica,23, 97-106.

Whittaker, R. H. (1972). Evolution and measurement of species diversity. Taxon, 21, 213-251. 